\section{No Peace for the Wicked}

SiR,--I do not wish to deal with all the points made by Dr Peggy Ellis in her comment on your editorial (Nature, 224,$929 ; 1969$ ), but I must deal with one major assumption she made, because it is critically important, yet seldorn challenged. She states, "At present the world population is too large for the amount of food available, in spite of continued agricultural advances". The assump. tion quite clearly is that, given our present knowledge, the population is too large for the world to support.

No one can deny that too little food is being produced, but that is far from being the same thing. The natural laws of economics operate for the production of food as for the production of ball-point pens, colour television sets or luxury yachts; all will be produced if, and only if, there is effective demand for them. And effective demand means not just need, but something to give in exchange.

The general world shortage of food arises almost entirely because those who need food have no effective demand. Why this should be is unfortunately outside the normal scope of this publication, but I hope I may be permitted a general observation. In a community where wealth is moderately evenly distributed, virtually every person will have sufficient effective demand for the most basic of requirements, food. In these circumstances the production of food will be at a maximum. In societies where wealth is heavily concentrated, although the total effective demand may be the same, the goods produced will be very different, and in the midst of hunger, workers will turn from the production of food to the manufacture of luxuries.

I hope that in time Dr Ellis and others will come to realize that the terrible problem of world hunger can be solved far more easily by slight changes in our economic system than by the most incredible advances in agricultural techniques.

\section{Yours faithfully,}

K. W. Baynes and Company,

K. W. BAYNeS

Pavement House,

1193 High Road,

Chadwell Heath,

Romford, Essex RM6 4AP.

\section{New Clothes for Old Body}

SIR,-I would like to correct the statement that epidemiology "will eventually be dropped" from the programme of the MRC Statistical Research and Services Unit ${ }^{1}$. Although some epidemiological enquiries have been transferred to Oxford with Professor Doll, others remain among our major continuing interests; the unit is, for example, contributing to the development of an important long-term international study on the epidemiology of tuberculosis ${ }^{2}$. Moreover, a medical statistics unit, which by definition is concerned with numerical aspects of disease in groups of individuals, and which also has an explicit commitment to advise Medical Research Council staff over the whole range of medical statistics, must inevitably continue to be involved in epidemiological problems.

\section{Yours faithfully,}

IAN SUthurLand

Medical Research Council,

Statistical Research and Services Unit,

University College Hospital Medical School,

115 Gower Street, London WC1.

1 Nature, 224, 841 (1969).

- Styblo, K., Meijer, J., and Sutherland, J., Bull. Int. Un. Tuberc., 42, 5 (1969) "(French translation in Bull. Wld'Hlth Org., in the press).

\section{University News}

Dr P. P. Benham has been appointed to the second chair of mechanical engineering at the University of Belfast.

Dr J. F. Tait, Worcester Foundation for Experimental Biology, Massachusetts, has been appointed to the Joel chair of physics as applied to medicine tenable at the Middlesex Hospital Medical School, University of London.

The title of professor of endocrine physiology has been conferred on Dr J. Lee in respect of his post at Charing Cross Hospital Medical School, University of London. The title of professor of radiation biology has been conferred on Dr Patricia J. Lindop in respect of her post at St Bartholomew's Hospital Medical College, University of London.

The title of professor of chemical pathology has been conferred on Dr G. R. Webster in respect of his post at Guy's Hospital Medical School, University of London.

\section{Announcements}

The Astronomical Society of the Pacific has awarded its bronze medal to Dr R. L. Waterfield of The Observatory, Woolston, Yeovil, Somerset, in recognition of his work on comets.

The City Migraine Clinic will be opened on May 20, 1970 , as an out-station of St Bartholomew's Hospital. It will provide immediate medical attention for the migraine sufferer who has an attack during office hours. The clinic will be financed by The Migraine Trust, 23 Queen Square, London WCl.

\section{International Meetings}

January 6, Legumes as Food-Breeding to Consumption, London (Mrs A. Shergold, Institute of Food Science and Technology, 41 Queen's Gate, London SW7). January 19-23, Technological Economics and Innovation in Pesticide Manufacture, Stirling (Mrs B. Morgan, Short Course Officer, University of Stirling, Stirling, Scotland).

January 26-30, Technological Economics and Innovation in Pesticide Use, Stirling (Mrs B. Morgan, Short Course Officer, University of Stirling, Stirling, Scotland). April 29-May 3, Protides of the Biological Fluids, Bruges (Dr H. Peeters, 18th Colloquium on Protides of Biological Fluids, POB 71, 8000 Brugge, Belgium).

July 4-18, Summer School in Theoretical Chemistry, Oxford (Professor C. A. Coulson, Mathematical Institute, 24-29 St Giles, Oxford OXI 3LB, UK).

July 6-9, Ferrites, Kyoto (Dr M. Sugimoto, Institute of Physical and Chemical Research, Yamato-Machi, Saitama Prefecture, Japan).

July 6-10, 3rd International Symposium on Passivity, Cambridge (Dr T. P. Hoar, Chairman, Local Arrangements Committee, e/o Metallurgy Department, University of Cambridge, Cambridge, UK).

July 6-12, Annual Meeting of the Society of Nuclear Medicine, Washington (Mrs M. Glos, Administrator, Society of Nuclear Medicine, 211 East 43rd Street, New York, NY 10017, USA).

July 8-10, Non-Aqueous Electrochemistry, Paris (Dr J. Badoz-Lambling, Laboratoire de Chimie Analytique, ESPCI, 10 rue Vauquelin, Paris 5, France).

July 8-11, Meeting of International Society of Endoscopy, Copenhagen (Dr S. Stoichita, 29 rue Pital Mos, Bucharest, Rumania). 